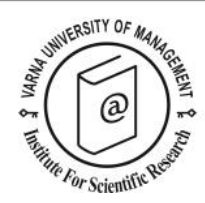

\title{
Italian corporate museums as industrial tourism destinations: A segmentation study based on strategic orientation
}

\author{
Angelo Riviezzo ${ }^{1 *}$, Antonella Garofano², Michela C. Mason ${ }^{3}$ \\ and Maria Rosaria Napolitano ${ }^{4}$
}

\footnotetext{
${ }^{1}$ University of Sannio, Italy. E-mail: angelo.riviezzo@unisannio.it.

${ }^{2}$ University of Campania L. Vanvitelli, Italy. E-mail: antonella.garofano@unicampania.it

3 University of Udine, Italy. E-mail: michela.mason@uniud.it

4 University of Naples Parthenope, Italy. E-mail: mariarosaria.napolitano@uniparthenope.it

${ }^{*}$ Corresponding author
}

\begin{abstract}
The main aim of this study is to propose a segmentation of Italian corporate museums, based on their strategic orientation and their actual willingness to cooperate with other local stakeholders in order to enhance industrial tourism in the area. The study is based on empirical data collected from 88 Italian museums belonging to private firms. A cluster analysis was used to identify three different groups of corporate museums, shedding light on the diverse role played as platforms from which firms may directly communicate with tourists and other stakeholders. The results of the study demonstrate the high heterogeneity of corporate museums, whose strategic priorities and orientation may vary significantly. Such variety has relevant implications for their potential role in the enhancement of the tourist attractiveness of the area.
\end{abstract}

Key words: corporate museum; industrial tourism; strategic orientation; cluster analysis; Italy.

Citation: Riviezzo, A., Garofano, A., Mason, M.C. and Napolitano, M.R. (2021). Italian corporate museums as industrial tourism destinations: A segmentation study based on strategic orientation. European Journal of Tourism Research 29, 2906. 


\section{Introduction}

In the last decades industrial heritage sites emerged as alternative tourist destinations and their recovery was the key of revitalization processes aimed at giving new opportunities to de-industrialized cities and regions (Boros et al., 2013). However, despite the growing importance gained worldwide, industrial tourism still remains a relatively unexplored topic, lacking a holistic and univocal definition (Otgaar et al., 2010). In a growing number of cities and regions strongly affected by deindustrialization processes, industrial landscapes have been transformed in consumption places, and testimonies of industrial past have become attractive for tourists (Xie, 2006). In this perspective, former industrial sites represent the core attraction of industrial heritage tourism, which Frew (2008) distinguished from industrial tourism, focused on the visit to operational industrial sites. More recently, Otgaar (2012) defined industrial tourism as "visits to sites that enable residents and tourists to get acquainted with a region's operational firms" (p. 87). In this relatively broad definition of industrial tourism, industrial heritage sites are only included if they require the participation of operational firms, but the core attractions are company tours, aimed at providing direct knowledge of production processes.

Within this general framework, corporate museums deserve particular attention since they provide, along with archives and brand parks, unique opportunities to learn about both industrial/organizational history and actual production processes (Chen and Morrison, 2004; Otgaar, 2012). Thus, they represent a key attraction for tourists interested in discovering the historical heritage of companies and local traditions.

In recent years, corporate museums have attracted scholarly attention mainly in the field of heritage marketing, where they have been investigated as precious sites of organizational memory (Nissley and Casey, 2002) and as useful tools for the enhancement of historical and cultural legacies of long-lived firms (Amari, 2001; Montella, 2010, 2012; Riviezzo et al., 2016; Napolitano et al., 2018; Garofano et al., 2020). However, despite such growing interest towards corporate museums, several aspects remain under-explored both in management and tourism fields. Namely, the way corporate museums are managed and the strategy they pursue to assure the development of industrial tourism in the area, by cooperating with other local organizations while sustaining the achievement of their owning firms' strategic objectives, still remain without explanations. In fact, most of the existing studies on and categorizations of corporate museums are focused on the materials they preserve or the display methods or the nature of the institution responsible for the collection and management of the artefacts (e.g., Amari, 2001; Negri, 2003; Bulegato, 2008). To the best of our knowledge, no research efforts have been made to investigate and classify corporate museums in the light of their strategic orientation and their actual willingness to cooperate with other local stakeholders in order to enhance industrial tourism in the area. Such an investigation can help to avoid the mistake to consider the presence of a corporate museum in a place as a condition able to assure "per se" a boost in local tourism. On the contrary, only if a corporate museum is strategically oriented to take an active role and to establish long-lasting relationships with other institutions, the effect of its presence on the tourist attractiveness of the area will be significant.

Following this line of reasoning, the idea that inspired the present study was to investigate corporate museums as a means through which private firms may play an active role in the development of industrial tourism, thus producing an impact both at business and territorial levels. In our view, corporate museums might represent a valuable tool of interaction between firms and society that could promote socio-economic development and create new opportunities for the expansion of this form of tourism. Thus, focusing on Italy, we propose a categorization of corporate museums based on empirical data assessing their strategic orientation, by means of a cluster analysis. 
In the following sections we briefly present the theoretical background of the study, our method and the results, followed by discussion and conclusions, along with limitations and directions for future research.

\section{Theoretical background}

\section{Industrial tourism}

In recent years, industrial tourism emerged as a promising branch in the tourism market, even if the different and sometimes conflicting views on its definition and scope make it difficult to obtain reliable statistics on the phenomenon (Otgaar, 2012). Indeed, different visions flow in this relatively new field of study, which can be placed at the intersection between cultural tourism and leisure. As highlighted by Frew (2008), the growing interest towards the topic resulted in a significant production of press articles and books, while few academic contributions came later and were mainly empirical in nature, with a lack of attention from a conceptual standpoint.

In line with a quite broad definition, this special type of tourism involves visits to industrial sites with the aim of learning about economic activities in the past, the present, and the future (Otgaar, 2012). More specifically, Frew (2008) refers to "operational industrial sites where the core activity of the site is non-tourism oriented" (p. 30) as the key attractions of industrial tourism, and so highlights the difference with industrial heritage tourism, which involves the restoration and exploitation of former industrial sites. This distinction is widely accepted in literature, where industrial heritage is considered as a specific form of cultural heritage emerging from deindustrialization and comprising sites that have been preserved and transformed into valuable resources for regeneration (Yang, 2017). According to Edwards and Llurdés (1996), industrial heritage tourism represents a distinctive, even if underresearched, subset in the broader field of heritage tourism, which has long focused on archaeological and conservation aspects. However, in recent years researchers and practitioners have turned their attention towards the tourism potential of "man-made sites, buildings and landscapes that originate with industrial processes from earlier periods" (Edwards and Llurdés, 1996, p. 342). Much could be discussed about the value of industrial heritage, which does not depend on its artistic relevance, but on its significance as a witness of industrial past and on its impact on the evolution of society (Cole, 2004). A feeling of nostalgia pervaded the first initiatives launched in the traditional industrial regions of Europe, where the decline of coal, steel and other heavy industries left many empty spaces to recover and determined an immediate need for their transformation (Hospers, 2002). Therefore, in several deindustrialized areas, such as the Ruhr in Germany or the northeast of England, tourism has been promoted as a useful form of regional restructuring and socio-economic development (Boros et al., 2013). As noted by Hospers (2002), the turn to industrial heritage tourism represented an interesting "new combination" for the so-called Europe's rustbelt, even if the acceptance of industrial monuments as tourist attractions was anything but simple. Many initiatives were undertaken to promote industrial tourist activities, not only at a local level, and a European Route of Industrial Heritage (ERIH) was created with the aim of networking more than 1,ooo industrial sites across the continent. Obviously, the development of industrial heritage tourism followed different paths and included unique sets of industrial monuments, depending on the industrial history of each region and/or country (Edwards and Llurdés, 1996). Specifically, Hospers (2002) grouped industrial tourist attractions in three main categories: industrial relicts in the field of production and processing, including sites located underground (like mines) and often partially transformed in museums which show the history of industrial occupations; transport attractions, including the industrial legacies in the fields of rail, water and roads, restored to offer the visitors alternative travel experiences; finally, socio-cultural attractions linked to the industrial past of a specific region, such as former working-class houses. Along with the potential effects in terms of economic restoration, several contributions also pointed out how the 
intangible value enclosed in the local industrial past may enhance the residents' identity and improve a region's image (Xie, 2006).

Moving away from tourism activities focused on industrial archaeology, in recent years a growing number of scholars identified the observation of production processes as an essential component of industrial tourism. The increasing interest towards factory tours, company visits and industrial sightseeing, often used as synonyms of industrial tourism (Otgaar et al., 2010; Otgaar, 2012; Lee, 2016), determined a significant extension of this field of study, whose object is now far beyond industrial heritage and its protection. According to Frew (2008), industrial tourism includes those attractions "where tourists do experience the behind the scenes aspects of operating an attraction" (p. 28). In this line of thought, Otgaar (2012) pointed out that the growing interest for authentic and unique experiences is among the main reasons for the increase in the demand for industrial tourism. The same author highlighted the role of industrial tourism for the improvement of the image of both individual firms and their home region; from his point of view, "industrial tourism can thus be regarded as tool of co-branding: branding places, products and producers all together" (Otgaar, 2012, p. 88). Accordingly, other contributions have investigated industrial tourism as a place marketing tool to be used in the competition between regions, also outlining its role in enhancing the relationship between business and society (Otgaar, 2010 et al.). Other contributions labeled industrial tourism as "consumer experience tourism" (Mitchell and Mitchell, 2001) and pointed out the advantages for companies that decide to engage in this activity, such as the creation of a bond between consumers and brand, the increase of brand loyalty, the improvement of brand image (Mitchell and Orwig, 2002). The initial narrow focus of industrial tourism on particular sectors, such as food and beverage, gradually extended to almost all sectors of the economy, including service industries (Frew, 2008). Therefore, all visits to both privately and publicly owned companies motivated by leisure and/or education purposes seem to fall under the broad definition of industrial tourism (Otgaar et al., 2010). In line with this extended definition, both theory and practice have focused on the incorporation of tourism in the strategies of firms, directly by opening their doors but also through corporate museums and archives.

\section{Corporate museums}

A growing body of research is drawing attention to the history of a company and its related heritage as a source of competitive advantage (Napolitano et al., 2018). In this broad field of study, corporate museums gained considerable interest as valuable tools to enhance and display tangible and intangible traces of organizational past (Danilov, 1992). At the same time, corporate museums emerged as alternative tourist destinations, able to economically activate forgotten peripheral areas and expand the city's cultural offer (Piatkowska, 2014). Although corporate museums are not a new phenomenon in industrialized countries, a definition univocally shared by management scholars and practitioners is still missing. At the beginning of the twentieth century, industrial heritage museums were created in the US with the aim of tracing the development of single industries and uncovering the human dimensions of industrial milieus (Lane, 1993). Subsequently, the general label of company museum came to include all those long-lasting institutes established to record the historical memory of a firm (Coleman, 1943).

Despite its recognition as a specific type of cultural institute, scientific literature still lacks a conceptual systematization of corporate museums, whose multifaceted nature makes it more difficult to achieve a univocal classification. It must be noted, for example, that various types of collections and archives are generically labeled as business museums and this not only causes definitional ambiguities but also methodological issues (Montella and Cerquetti, 2016). According to the definitions provided in literature (e.g., Danilov, 1992; Nissley and Casey, 2002), business museums include those institutions 
open to the public which conserve, display and enhance documents and objects that witness the history and the evolution of an industry (in the case of industrial museums), of a district rooted in a specific territory (in the case of district museums), of a company (in the case of corporate museums). In the present study, we focus on corporate museums owned and operated by private companies, considered as depositories of tangible and intangible traces of organizational history (Ravasi et al. 2018), to be exploited also for tourism purposes.

It is worth highlighting that in the last years corporate museums have significantly changed their nature and scope. As highlighted by Nissley and Casey (2002), they can be seen as strategic assets able to impact on organizational decisions and activities, based on a combination of displayed artefacts and the socially constructed story they conserve and communicate. Therefore, the vision of corporate museums has significantly changed, with a shift from a passive collection of organizational artefacts (Danilov, 1992), to an "extension of the organization's public relations and marketing efforts" (Nissley and Casey, 2002, p. 3). As a consequence, a growing number of studies investigated corporate museums as marketing and communication tools, also focusing on the creation of an organizational narrative identity (Riviezzo et al., 2016) and the strengthening of corporate image (Montella, 2010). Furthermore, corporate museums have been considered for their contributions to the engagement of internal and external stakeholders (Napolitano et al., 2018) and to the emotional involvement of visitors (Montemaggi and Severino, 2007). Despite the research efforts made in the last years, several aspects necessary to get a complete picture of corporate museums from a management perspective remain under-explored. In fact, strategic characteristics of corporate museums and their owning companies were substantially neglected, since prior research has largely given attention to cultural, historical and artistic aspects. Furthermore, due to the focus on single case studies, large-scale investigations are at a great extent lacking and the only existing categorizations are based on the type of collection displayed in the museums (Amari, 2001), on the preserved materials and the display methods (Negri, 2003) or on the nature of the institution responsible for the collection and management of the artefacts (Bulegato, 2008).

Moreover, there is no univocal vision in literature about the inclusion of corporate museums among industrial tourism attractions nor on the specific role they play in this context. Focusing on a site's reason for existence, Frew (2008) considers corporate museums as "pure consumer tourism", thus excluding them from the notion of industrial tourism. Conversely, several contributions recognized corporate museums as an integral part of industrial tourism (e.g., Chen and Morrison, 2004; Otgaar, 2012). Even considering the central role of corporate museums for the diffusion of industrial culture, few efforts have been made to investigate the role they may play as platforms from which firms can directly communicate with tourists and other stakeholders, without interfering with the production process.

Based on the above-mentioned circumstances, the main aim of this study is precisely to fill this gap in the literature and therefore to propose a segmentation of corporate museums, based on empirical data collected in Italy, assessing their strategic orientation and their contribution to the development of industrial tourism in the country.

\section{Methodology}

Data collection and sample

The objectives of the present study were achieved by analysing empirical data collected through a survey among corporate museums located in Italy. 
Compared to other European countries, such as Great Britain and Germany, the phenomenon of corporate museums developed with some delay in Italy, but with a rapid spread. Based on previous studies (e.g., Danilov, 1992; Stigliani and Ravasi, 2007), it is esteemed that in the early nineties about half of all corporate museums were in Italy. As a consequence of such diffusion, over the last years big expectations emerged towards these attractions as a new possibility to revitalize and differentiate touristic offer of many places. But, apart from some well-known cases, for which the tourist attractiveness has been certified by the incredible number of visitors (see, for instance, Montella and Cerquetti, 2016; Garofano et al., 2017, 2020; Napolitano et al., 2018; 2020), there are no figure and data about the real impact of this form of tourism. And, more importantly, there are no information about the real involvement of corporate museums in the development of industrial tourism in the country. This is the reason why Italy seems to be the ideal research setting for investigating this topic.

We focused on museums belonging to private firms and run directly by the firm itself or through a foundation. By triangulating data gathered from secondary sources, including previous studies, we identified a total number of 116 museums. We contacted each museum by phone; after presenting the research project, we sent out a survey to be completed online by our key-informant, identified with the museum director or curator. Follow-up emails and phone calls were used with those museums that did not answer to the survey on the first attempt.

A total of 88 completed and usable questionnaires were returned, that means a response rate of about $76 \%$. The investigated museums operate across different industries and differ significantly in terms of size (83\% with less than 5 employees; $5.6 \%$ with more than 10$)$ and geographical distribution (60.2\% located in the north of Italy; $26.2 \%$ located in the centre; and $13.6 \%$ in the south of the country). It is worth noting that: since 2000 the number of corporate museums has increased by $50.4 \%$; only $33 \%$ require an admission fee, while others' admission is free of charge.

\section{Measures and validation}

We used an online structured questionnaire to investigate museum's strategic orientation and descriptive features (e.g., year of establishment, number of employees, opening hours, etc.). The items used to operationalize museum's strategic orientation were derived and adapted from previous studies and, in some cases, were self-developed. Considering the nature of corporate museums, we discussed in the theoretical background of this study and the paucity of research within the specific context of corporate museums, we considered previous studies focusing on the strategic orientation either of museums in general or firms operating in cultural and creative industries.

We included items related to the need for corporate museums to be attractive for visitors and tourists (i.e., external stakeholders orientation) and, at the same time, to engage with employees, managers and other internal stakeholders of the owning company (i.e., internal stakeholders orientation). The items used to assess the external stakeholders orientation were taken from the "visitor orientation" scaleitems used by Camarero and Garrido (2012); the items used to assess the internal stakeholders orientation were derived, and partially adapted, from the "donor orientation" scale-items used in the same study (Camarero and Garrido, 2012).

Furthermore, we focused on the need for corporate museums to become part of the tourist offer of the area, collaborating with other local touristic institutions (i.e., collaborative orientation). The items were taken from Camarero and Garrido (2012). 
At the same time, as a company's asset, we considered the need to contribute to the achievement of its strategic aims (i.e., firm-museum coordination). In this case the items were adapted from the "interfunctional coordination" scale-items used in previous studies on public museums (Camarero and Garrido, 2008; 2012) and other arts organizations (Voss and Voss, 2000).

Following this reasoning, we investigated if the contribution of the museum to a company's objectives is mainly related to business opportunities, in terms of tickets revenues, museum shop sales, etc. (i.e., business orientation) and/or in terms of company's image, knowledge and skills (i.e., development orientation). In order to assess the business orientation, we used items partially adapted from Camarero and Garrido (2008), while in order to measure the development orientation we self-developed items based on theoretical contributions of previous studies (e.g., Napolitano et al., 2018).

Finally, we included items related to the ability of corporate museums to innovate their offer and organizational model (i.e., innovation orientation). The items were taken from Camarero and Garrido (2012). The full list of items is shown in Table 1. The items were assessed on a 5-points Likert scale, ranging from " $1=$ totally disagree" to " $5=$ totally agree".

Table 1. Exploratory factor analysis

\begin{tabular}{|c|c|c|c|c|c|}
\hline & Mean & $\begin{array}{l}\text { Std. } \\
\text { Dev. }\end{array}$ & $\begin{array}{l}\text { Factor } \\
\text { loading }\end{array}$ & $\begin{array}{l}\text { Variance } \\
\text { explained (\%) }\end{array}$ & $\begin{array}{l}\text { Cronbach's } \\
\alpha\end{array}$ \\
\hline F1: External stakeholder orientation & & & & $10.9 \%$ & 0.842 \\
\hline $\begin{array}{l}\text { Strategy and museum's goals are oriented } \\
\text { towards visitors satisfaction }\end{array}$ & 4.09 & 0.97 & 00.687 & & \\
\hline $\begin{array}{l}\text { We endeavour to keep abreast of changes so as to } \\
\text { assess their impact on visitors' needs }\end{array}$ & 3.32 & 1.10 & 0.602 & & \\
\hline $\begin{array}{l}\text { We constantly try to monitor visitors' needs and } \\
\text { expectations }\end{array}$ & 3.65 & 1.05 & 0.817 & & \\
\hline $\begin{array}{l}\text { Museum's initiatives are based on the visitors' } \\
\text { needs and expectations }\end{array}$ & 3.64 & 0.94 & 0.753 & & \\
\hline We regularly monitor visitors' satisfaction & 3.64 & 1.22 & 0.582 & & \\
\hline F2: Internal stakeholder orientation & & & & $10.3 \%$ & 0.852 \\
\hline $\begin{array}{l}\text { We endeavour to keep abreast of changes so as to } \\
\text { assess their impact on the firm's needs and its } \\
\text { internal customers (employees, managers, } \\
\text { shareholders) }\end{array}$ & 3.45 & 1.11 & 0.636 & & \\
\hline $\begin{array}{l}\text { Seeking to pinpoint how the museum can } \\
\text { support the company for achieving its goals is a } \\
\text { constant process }\end{array}$ & 3.97 & 0.99 & 0.802 & & \\
\hline $\begin{array}{l}\text { Museum's initiatives are aimed to support the } \\
\text { company goals }\end{array}$ & 4.06 & 0.94 & 0.837 & & \\
\hline $\begin{array}{l}\text { We regularly monitor museum's ability to create } \\
\text { value for the company and its internal customers }\end{array}$ & 3.74 & 1.14 & 0.718 & & \\
\hline F3: Collaborative orientation & & & & $6.5 \%$ & 0.875 \\
\hline $\begin{array}{l}\text { We make an effort to cooperate with other forms } \\
\text { of tourism or leisure which complement what we } \\
\text { have to offer }\end{array}$ & 3.69 & 1.34 & 0.889 & & \\
\hline $\begin{array}{l}\text { We cooperate with other cultural or leisure } \\
\text { institutions to provide alternatives for visitors or } \\
\text { to offer joint initiatives }\end{array}$ & 3.82 & 1.30 & 0.803 & & \\
\hline
\end{tabular}




\begin{tabular}{|c|c|c|c|c|c|}
\hline \multicolumn{4}{|l|}{ F4: Firm-Museum coordination } & \multirow[t]{4}{*}{$7.8 \%$} & \multirow[t]{4}{*}{0.832} \\
\hline Museum and company staff work closely together & $4 \cdot 5^{2}$ & 0.92 & 0.785 & & \\
\hline $\begin{array}{l}\text { The museum is concerned with ensuring that the } \\
\text { activities are well coordinated and consistent } \\
\text { with company goals }\end{array}$ & $4 \cdot 32$ & 0.97 & 0.650 & & \\
\hline $\begin{array}{l}\text { Company is directly involved in drawing up the } \\
\text { museum's strategy and goals }\end{array}$ & 4.25 & 1.02 & 0.821 & & \\
\hline \multicolumn{4}{|l|}{ F5: Innovation } & $9.8 \%$ & 0.921 \\
\hline $\begin{array}{l}\text { At the museum we are deeply committed to using } \\
\text { new resources and technologies to assist the } \\
\text { visiting public }\end{array}$ & 3.19 & 1.25 & 0.802 & & \\
\hline $\begin{array}{l}\text { At the museum we are deeply committed to } \\
\text { adopting new technologies and resources aimed } \\
\text { at improving management and administration }\end{array}$ & 2.86 & 1.23 & 0.848 & & \\
\hline $\begin{array}{l}\text { In general, we have incorporated numerous } \\
\text { technical innovations at the museum in recent } \\
\text { years }\end{array}$ & 2.75 & 1.22 & 0.891 & & \\
\hline \multicolumn{4}{|l|}{ F6: Business orientation } & $8.1 \%$ & 0.802 \\
\hline $\begin{array}{l}\text { The museum has achieved its objectives (visitor } \\
\text { numbers, notoriety, etc.) }\end{array}$ & 3.68 & 1.14 & 0.933 & & \\
\hline $\begin{array}{l}\text { The museum generates a volume of business in } \\
\text { according to the company's expectations } \\
\text { (considering tickets, shop, induced sales, etc.) }\end{array}$ & 2.74 & 1.44 & 0.595 & & \\
\hline $\begin{array}{l}\text { In general, we are very satisfied with museum's } \\
\text { outcomes }\end{array}$ & 3.85 & 1.01 & 0.745 & & \\
\hline \multicolumn{4}{|l|}{ F7: Development orientation } & $4.4 \%$ & 0.669 \\
\hline $\begin{array}{l}\text { The creation of the museum had a positive } \\
\text { impact on the company image }\end{array}$ & 3.78 & 1.03 & 0.730 & & \\
\hline $\begin{array}{l}\text { The creation of the museum had a positive } \\
\text { impact on the development of company's } \\
\text { knowledge and skills }\end{array}$ & 3.61 & 1.10 & 0.653 & & \\
\hline
\end{tabular}

In order to validate the scales' items, we performed an exploratory factor analysis (EFA) using the Maximum Likelihood (ML) with a VARIMAX rotation, by means of the SPSS software, version 20. As recommended by Hair, Black, Babin and Anderson (2010) all factors with an eigenvalue equal to or greater than 1.0 were retained and all items with a factor loading equal to or above 0.6 and communality equal to or above 0.5 were included. Reliability coefficients (Cronbach's $\alpha$ ) were computed to estimate the internal consistency of the items within each factor. The results of exploratory factor analysis yielded a seven-factor solution, shown in Table 1.

All factors had relatively high reliability coefficients ranging from 0.669 to 0.921 . The total variance extracted of these seven factors accounted for about $58 \%$ of the total variance.

\section{Cluster analysis}

In order to develop a categorization of the investigated corporate museums based on their strategic orientation and their actual contribution to the development of industrial tourism in the area, we analysed empirical data with cluster analysis. Thus, the aforementioned seven factors were used to cluster respondents into homogeneous groups. We used both hierarchical cluster analysis (HCA) and 
k-means cluster procedure. The HCA was used as a preliminary step in determining the number of clusters best fitting the data. The dendrogram representing the HCA is illustrated in Figure 1.

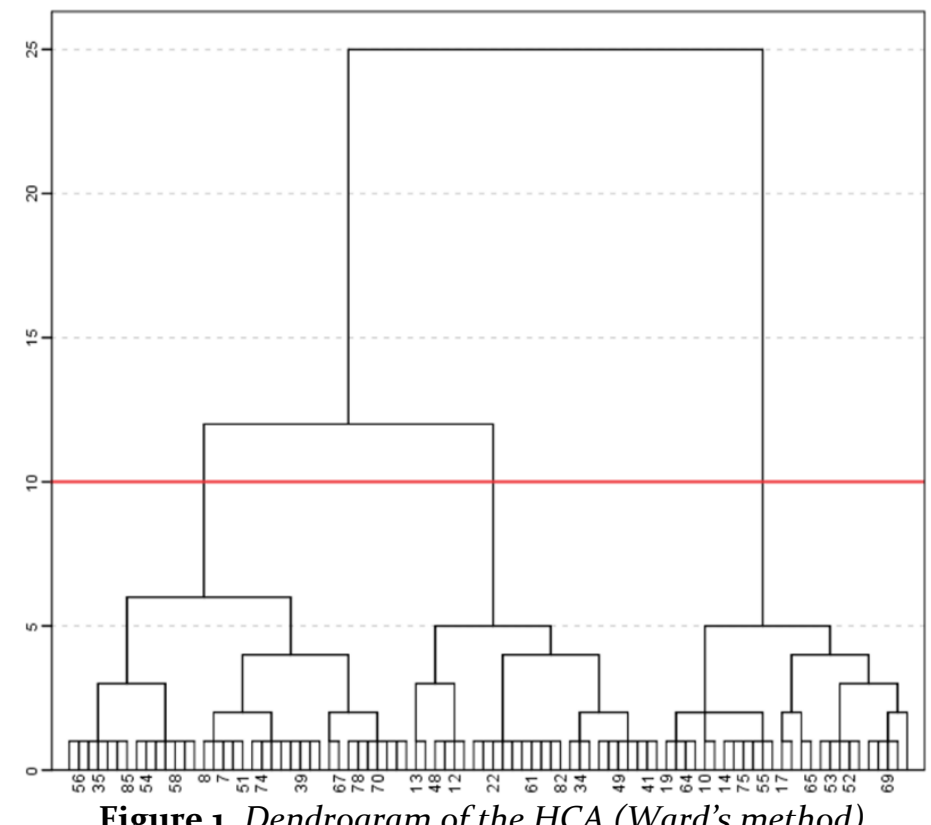

Figure 1. Dendrogram of the HCA (Ward's method)

Table 2. Multiple discriminant analysis

\begin{tabular}{|c|c|c|c|c|}
\hline \multirow[t]{2}{*}{ Clusters } & & & \multicolumn{2}{|c|}{ Group centroids } \\
\hline & & & Function 1 & Function 2 \\
\hline I & & & 0.771 & -2.390 \\
\hline II & & & 1.205 & 0.953 \\
\hline III & & & -3.028 & 0.213 \\
\hline Eigenvalue & & & $3 \cdot 389$ & 1.838 \\
\hline $\begin{array}{l}\text { Canonical } \\
\text { correlation }\end{array}$ & & & 0.879 & 0.805 \\
\hline Wilk's Lambda & & & 0.080 & 0.352 \\
\hline Chi-square & & & 206.82 & 85.53 \\
\hline Significance & & & $* * *$ & $* * *$ \\
\hline \multirow[t]{2}{*}{ Actual group } & \# of cases & \multicolumn{3}{|c|}{ Predicted group membership } \\
\hline & $\mathbf{N}$ & $\mathbf{I}$ & II & III \\
\hline $\mathbf{I}$ & 20 & $20(100 \%)$ & o & o \\
\hline II & 45 & o & $45(100 \%)$ & o \\
\hline III & 23 & o & o & $23(100 \%)$ \\
\hline
\end{tabular}

Bold figures indicate the number of respondents correctly classified in each cluster. Hit-ratio $=100 \%$

Based on the results, a three-cluster solution was selected in the subsequently k-means analysis. Then, discriminant analysis was performed to confirm the accuracy of the three-cluster solution. The results 
show that two discriminant functions were extracted, explaining the majority of variance $(65 \%$ and $35 \%)$. Wilks's lambda test and univariate $\mathrm{F}$ test show the factors make a statistically significant contribution to the discriminant functions. The canonical correlations for the two functions are high (> o.8) and significant $(\mathrm{p}<\mathrm{o.001})$, indicating that the model explains a significant relationship between the functions and the dependent variable. The classification matrix of respondents shows all cases classified correctly (Hair et al., 2010). The results of the discriminant analysis are summarized in Table 2.

\section{Results}

Cluster analysis allowed us to identify three clusters, significantly differing in terms of strategic aims, priorities and orientation. Namely, looking at the strategic priorities of the museums falling into the three groups, we propose the following segmentation:

Cluster I - "Traditionalist": this group comprises $23 \%$ of respondents and is characterized by the highest level of collaborative orientation with other forms of tourism or leisure, high level of development orientation and the lowest level of innovation. Thus, the museums in this group are not particularly committed to use new resources and technologies aimed at improving the quality of the experience they offer to visitors, but they take an active role in fostering the tourism in the area. They regularly cooperate with other cultural or leisure institutions to provide alternatives for visitors and to develop joint initiatives.

Cluster II - "Strategist": this is the largest cluster with $51 \%$ of respondents. This group assigned the highest level of importance to all strategic aspects, meaning that they give significant weight to the different functions that the museum can play, both for internal and external stakeholders. Thus, the museums in this group are committed to support the company goals, but at the same time they care about visitor satisfaction and the development of joint initiatives with other local firms and institutions to promote tourism in the area.

Cluster III - "Individualist": this segment includes $26 \%$ of the sample. It displays the importance of firmmuseum coordination. Collaborative orientation stands at minimum levels, whereas external stakeholder orientation is at a medium level as well as innovation. The museums in this group are "isolated" from the other forms of tourism or leisure that may complement their offer, and they do not cooperate with other cultural or leisure institutions to provide alternatives for visitors or to develop joint initiatives. In sum, they are not really concerned about the development of industrial tourism in the area.

In Figure 2 the different profiles of the three extracted clusters are represented, while Table 3 illustrates the strategic characteristics of the clusters more in details. 
Table 3. Cluster description

\begin{tabular}{ccc}
\hline Traditionalist & Strategist & Individualist \\
\hline $\mathrm{N}=\mathbf{2 0}(23) \%$ & $\mathrm{~N}=\mathbf{4 5}(5 \mathbf{1} \%)$ & $\mathrm{N}=\mathbf{2 3}(\mathbf{2 6 \%})$
\end{tabular}

\begin{tabular}{|c|c|c|c|c|c|c|c|c|}
\hline Factor & Mean & Std. Dev. & Mean & Std. Dev. & Mean & Std. Dev. & F-ratio & Sig. \\
\hline F1: External stakeholder orientation & 3.01 & 0.68 & 4.06 & 0.65 & $3 \cdot 41$ & 0.87 & 16.77 & $* * *$ \\
\hline Ext_stk_1 & 3.75 & 1.07 & 4.33 & 0.83 & 3.91 & 1.04 & 3.20 & ** \\
\hline Ext_stk_2 & 2.50 & 1.00 & 3.78 & 0.97 & 3.13 & 0.97 & 12.38 & $* * *$ \\
\hline Ext_stk_3 & 2.75 & 0.91 & 4.13 & 0.81 & 3.48 & 1.04 & 16.95 & $* * *$ \\
\hline Ext_stk_4 & 3.20 & 0.83 & 3.93 & 0.89 & 3.43 & 0.95 & 5.47 & $* * *$ \\
\hline Ext_stk_5 & 3.00 & 1.08 & 4.18 & 0.94 & 3.13 & 1.36 & 11.41 & $* * *$ \\
\hline F2: Internal stakeholder orientation & 3.54 & o.77 & 4.21 & 0.70 & 3.36 & 0.96 & 10.45 & $* * *$ \\
\hline Int_stk_2 & 2.90 & 1.25 & 3.73 & 1.01 & 3.39 & 1.03 & 4.22 & ** \\
\hline Int_stk_3 & 3.70 & 0.98 & 4.33 & 0.80 & 3.48 & 1.08 & 7.66 & $* * *$ \\
\hline Int_stk_4 & 4.00 & 0.86 & 4.38 & 0.78 & 3.48 & 1.04 & 8.19 & $* * *$ \\
\hline Int_stk_5 & 3.35 & 1.04 & 4.24 & 0.91 & 3.09 & 1.20 & 1.65 & $* * *$ \\
\hline F3: Collaborative orientation & 4.28 & 0.73 & $4 \cdot 42$ & 0.59 & 2.00 & 0.77 & 105.63 & $* * *$ \\
\hline Collab_1 & 4.15 & 0.81 & 4.40 & 0.72 & 1.91 & 1.00 & 73.99 & $* * *$ \\
\hline Collab_2 & 4.40 & 0.75 & 4.44 & 0.69 & 2.09 & 1.00 & 73.83 & $* * *$ \\
\hline F4: Firm-Museum coordination & 3.53 & 1.05 & 4.83 & 0.30 & 4.15 & 0.73 & 28.90 & $* * *$ \\
\hline Firm_coo_1 & 3.70 & 1.34 & 4.93 & 0.33 & 4.43 & 0.79 & 17.19 & $* * *$ \\
\hline Firm_coo_2 & 3.50 & 1.19 & 4.89 & 0.32 & 3.91 & 0.90 & 27.45 & $* * *$ \\
\hline Firm_coo_3 & $3 \cdot 40$ & 1.35 & 4.69 & 0.56 & 4.13 & 0.92 & 14.86 & $* * *$ \\
\hline F5: Innovation & 1.94 & o.8o & 3.62 & 0.90 & 2.45 & 0.97 & 28.62 & $* * *$ \\
\hline Inn_1 & 2.20 & 1.01 & 3.93 & 0.96 & 2.61 & 1.03 & 26.59 & $* * *$ \\
\hline Inn_2 & 1.90 & 0.91 & 3.56 & 1.03 & 2.35 & 1.03 & 22.81 & $* * *$ \\
\hline Inn_3 & 1.75 & 0.79 & 3.38 & 1.03 & 2.39 & 1.16 & 19.70 & *** \\
\hline F6: Business orientation & 3.20 & 0.95 & 3.88 & 0.95 & 2.92 & 0.87 & 9.06 & $* * *$ \\
\hline Bus_or_1 & $3 \cdot 40$ & 0.94 & 4.09 & 1.10 & 3.13 & 1.10 & 7.02 & $* * *$ \\
\hline Bus_or_2 & 2.70 & 1.30 & 3.20 & 1.42 & 1.87 & 1.22 & $7 \cdot 45$ & $* * *$ \\
\hline Bus_or_3 & 3.40 & 1.10 & 4.20 & 0.92 & 3.57 & 0.90 & 6.25 & $* * *$ \\
\hline F7: Development orientation & 3.76 & 0.77 & 4.06 & 0.83 & 2.97 & 0.79 & 13.84 & $* * *$ \\
\hline Dev_or_1 & 4.50 & 0.61 & 4.80 & 0.40 & 4.04 & 0.93 & 11.20 & $* * *$ \\
\hline Dev_or_2 & 3.85 & 0.93 & 4.11 & 0.91 & 3.09 & 1.04 & 8.89 & $* * *$ \\
\hline
\end{tabular}

Significance coefficients ${ }^{* * *} 1 \%$ level, ${ }^{* *} 5 \%$ level, ${ }^{*} 10 \%$ level 


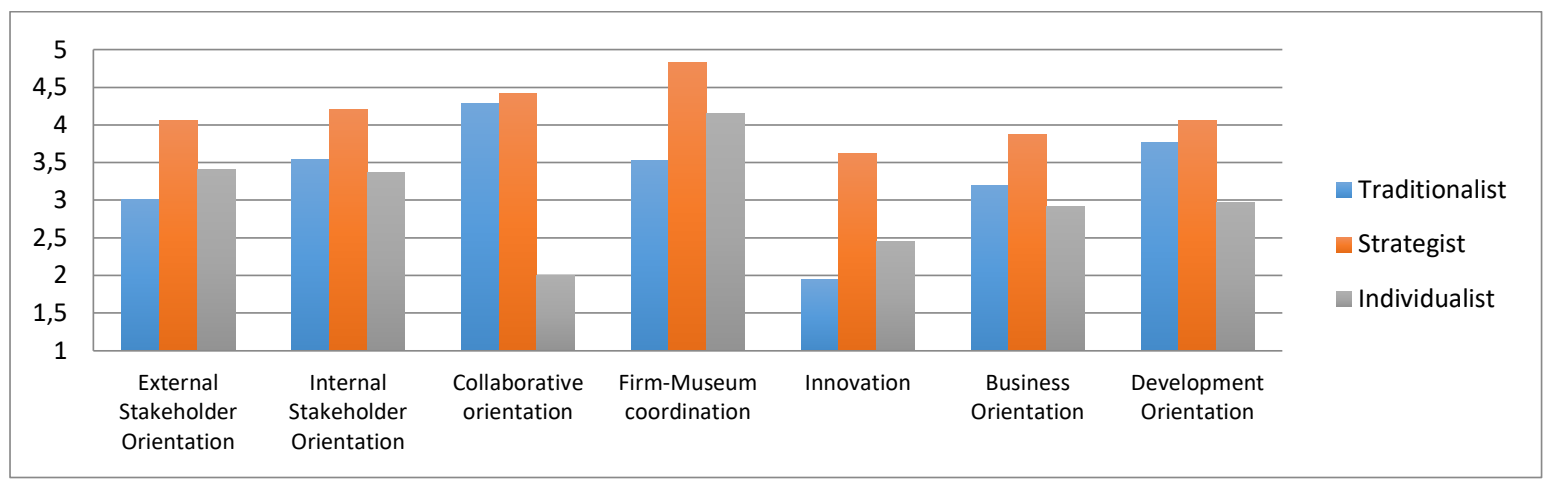

Figure 2. Clusters' profile

In order to identify the specific differences among the groups for each factor considered, a post hoc test was performed. The most significant difference among the three groups is in terms of firm-museum coordination, meaning that the degree of freedom the museums have in fixing their own objectives and partnerships is highly different for the traditionalist, the strategist and the individualist. The results of the post hoc test, as well as the pairwise comparison, are displayed in Table 4.

Table 4. Post Hoc test and group comparison

\begin{tabular}{|c|c|c|c|c|}
\hline Factor & Cluster & Mean & Comparison & Sig. \\
\hline & Traditionalist & 3.01 & Traditionalist vs Strategist & $* * *$ \\
\hline \multirow[t]{3}{*}{ External Stakeholder Orientation } & Strategist & 4.06 & Traditionalist $v s$ Individualist & * \\
\hline & Individualist & 3.41 & Strategist $v s$ Individualist & $* * *$ \\
\hline & Traditionalist & $3 \cdot 54$ & Traditionalist vs Strategist & *** \\
\hline \multirow[t]{3}{*}{ Internal Stakeholder Orientation } & Strategist & 4.21 & Traditionalist $v s$ Individualist & * \\
\hline & Individualist & 3.36 & Strategist $v s$ Individualist & *** \\
\hline & Traditionalist & 4.28 & Traditionalist $v s$ Strategist & * \\
\hline \multirow[t]{3}{*}{ Collaborative Orientation } & Strategist & 4.42 & Traditionalist $v s$ Individualist & *** \\
\hline & Individualist & 2.00 & Strategist $v s$ Individualist & *** \\
\hline & Traditionalist & 3.53 & Traditionalist $v s$ Strategist & $* * *$ \\
\hline \multirow[t]{3}{*}{ Firm-Museum Coordination } & Strategist & 4.83 & Traditionalist $v s$ Individualist & $* * *$ \\
\hline & Individualist & 4.15 & Strategist $v s$ Individualist & *** \\
\hline & Traditionalist & 1.94 & Traditionalist $v s$ Strategist & $* * *$ \\
\hline \multirow[t]{3}{*}{ Innovation } & Strategist & 3.62 & Traditionalist $v s$ Individualist & * \\
\hline & Individualist & 2.45 & Strategist $v s$ Individualist & *** \\
\hline & Traditionalist & 3.20 & Traditionalist $v s$ Strategist & *** \\
\hline \multirow[t]{3}{*}{ Business Orientation } & Strategist & 3.88 & Traditionalist $v s$ Individualist & * \\
\hline & Individualist & 2.92 & Strategist $v s$ Individualist & $* * *$ \\
\hline & Traditionalist & 3.76 & Traditionalist $v s$ Strategist & * \\
\hline \multirow[t]{2}{*}{ Development Orientation } & Strategist & 4.06 & Traditionalist $v s$ Individualist & $* * *$ \\
\hline & Individualist & 2.97 & Strategist vs Individualist & *** \\
\hline
\end{tabular}

Significance coefficients $* * * 1 \%$ level, $* * 5 \%$ level, $* 10 \%$ level 
The three clusters were further cross-tabulated using the variables of geographical area, entrance mode, museum schedule, number of employees, industry and year of foundation (Table 5). Significant differences emerged only in the entrance mode and in the timetable adopted by the three groups. The "individualist" group is composed of $87 \%$ of free entrance museums, while in the other two clusters the entrance mode is almost equally distributed between free and paid. Looking at the museums' timetables, the "traditionalist" group is composed by museums whose timetables are equally distributed between pre-determined and arrangeable, while the "strategist" group and the "individualist" group display symmetrically opposite paths: the first is characterized by the strong presence of museums with pre-determined timetables, while the second presents the opposite trend.

Table 5. Cluster profiling

\begin{tabular}{|c|c|c|c|c|c|c|c|c|c|}
\hline & & \multirow{3}{*}{\multicolumn{2}{|c|}{$\begin{array}{c}\text { Traditionalist } \\
\text { Frequencies }\end{array}$}} & \multirow{3}{*}{\multicolumn{2}{|c|}{$\begin{array}{c}\text { Strategist } \\
\text { Frequencies }\end{array}$}} & \multirow{3}{*}{\multicolumn{2}{|c|}{$\begin{array}{l}\text { Individualist } \\
\text { Frequencies }\end{array}$}} & \multirow{4}{*}{$\begin{array}{c}\begin{array}{c}\text { Chi- } \\
\text { squared }\end{array} \\
5.599\end{array}$} & \multirow{4}{*}{ Sig. } \\
\hline & & & & & & & & & \\
\hline & & & & & & & & & \\
\hline \multirow{3}{*}{ Geographic Area } & Center & 6 & $30 \%$ & 12 & $27 \%$ & 5 & $22 \%$ & & \\
\hline & North & 13 & $65 \%$ & 25 & $56 \%$ & 15 & $65 \%$ & & \\
\hline & South & 1 & $5 \%$ & 8 & $17 \%$ & 3 & $13 \%$ & & \\
\hline \multirow{2}{*}{ Admission } & Free & 11 & $55 \%$ & 28 & $62 \%$ & 20 & $87 \%$ & $5 \cdot 914$ & * \\
\hline & Paid & 9 & $45 \%$ & 17 & $38 \%$ & 3 & $13 \%$ & & \\
\hline \multirow{4}{*}{$\begin{array}{c}\text { Museum } \\
\text { timetables }\end{array}$} & Set timetable & 11 & $55 \%$ & 31 & $69 \%$ & 9 & $39 \%$ & 8.931 & * \\
\hline & Arrangeable timetable & 9 & $45 \%$ & 12 & $27 \%$ & 14 & $61 \%$ & & \\
\hline & Events and special & o & o\% & 2 & $4 \%$ & o & o\% & & \\
\hline & occasions & & & & & & & & \\
\hline \multirow{5}{*}{ Employees } & $<10$ & 8 & $40 \%$ & 18 & $40 \%$ & 8 & $35 \%$ & 6.570 & \\
\hline & $11-50$ & 5 & $25 \%$ & 6 & $13 \%$ & 5 & $22 \%$ & & \\
\hline & $51-100$ & o & o\% & 4 & $9 \%$ & 4 & $17 \%$ & & \\
\hline & $101-200$ & 1 & $5 \%$ & 1 & $2 \%$ & o & o\% & & \\
\hline & $>200$ & 6 & $30 \%$ & 16 & $36 \%$ & 6 & $26 \%$ & & \\
\hline \multirow{8}{*}{ Industry } & Food & 3 & $15 \%$ & 8 & $18 \%$ & 4 & $18 \%$ & 10.473 & \\
\hline & Design & 2 & $10 \%$ & 6 & $14 \%$ & 1 & $4 \%$ & & \\
\hline & Fashion & 3 & $15 \%$ & 2 & $4 \%$ & 1 & $4 \%$ & & \\
\hline & Jewelry & o & o\% & 2 & $4 \%$ & o & o\% & & \\
\hline & Transportation industry & 3 & $15 \%$ & 3 & $7 \%$ & 2 & $9 \%$ & & \\
\hline & Construction industry & o & o\% & o & o\% & 1 & $4 \%$ & & \\
\hline & Services & 1 & $5 \%$ & 2 & $4 \%$ & 2 & $9 \%$ & & \\
\hline & Other & 8 & $40 \%$ & 22 & $49 \%$ & 12 & $52 \%$ & & \\
\hline \multirow{4}{*}{ Year } & $<1990$ & 3 & $15 \%$ & 12 & $27 \%$ & 4 & $18 \%$ & 5.679 & \\
\hline & $1990-2000$ & 8 & $40 \%$ & 7 & $15 \%$ & 6 & $26 \%$ & & \\
\hline & $2000-2010$ & 6 & $30 \%$ & 17 & $38 \%$ & 7 & $30 \%$ & & \\
\hline & $>2010$ & 3 & $15 \%$ & 9 & $20 \%$ & 6 & $26 \%$ & & \\
\hline
\end{tabular}

Significance coefficients *** $1 \%$ level, ${ }^{* *} 5 \%$ level, * $10 \%$ level 
Figure 3 illustrates the clusters' geographic location in Italy, divided by the three clusters. The main percentage of corporate museums is located in Northern Italy (i.e., 6o\%), 26\% is placed in Central Italy and $14 \%$ in the Southern Italy. Only one corporate museum is situated in Insular Italy (i.e., Sicily). The Region with the largest number of corporate museums is Lombardy, followed by Piedmont and Umbria.

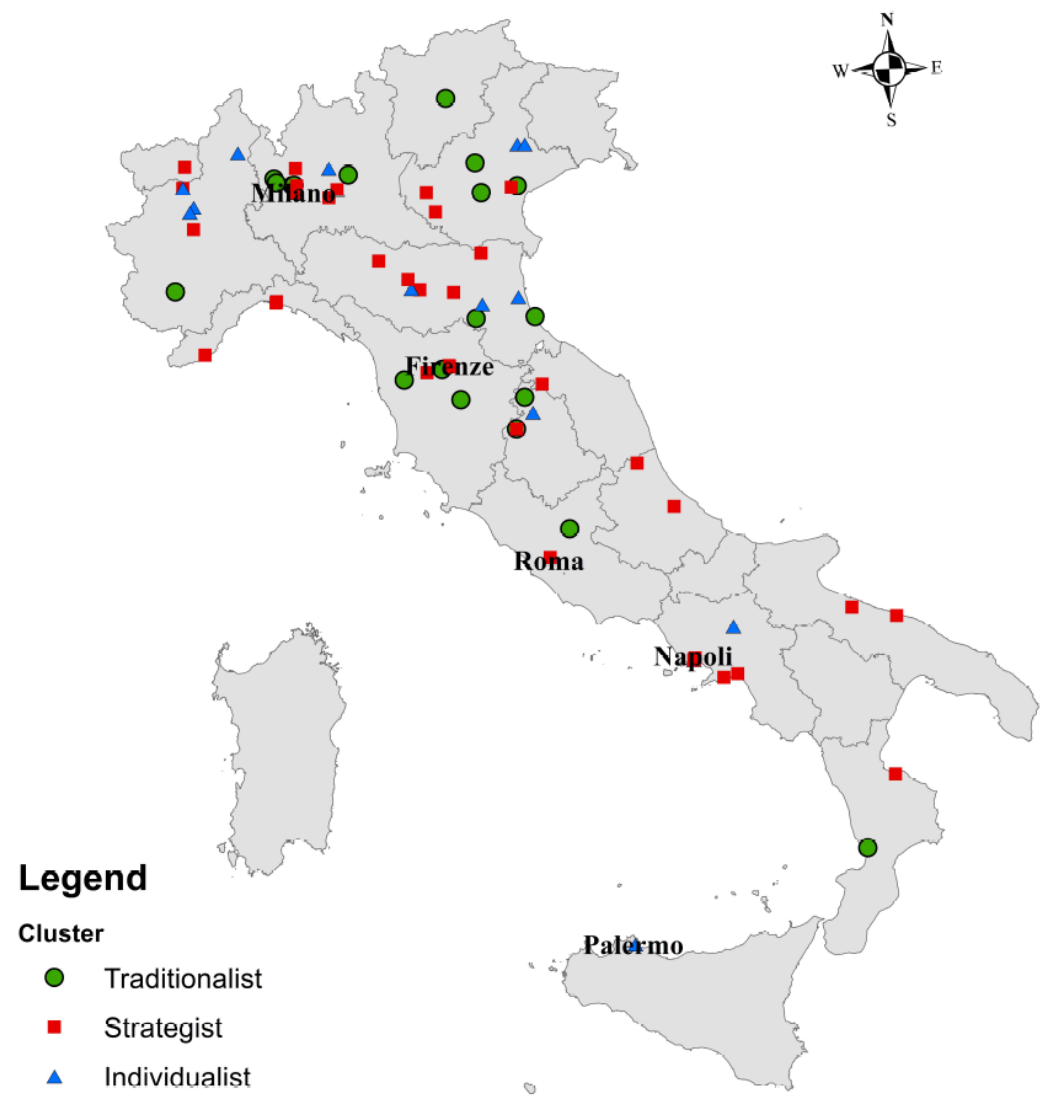

Figure 3. Distribution of clusters in Italy

\section{Discussion and implications}

In recent years corporate museums experienced a rapid spread and significantly expanded their role and objectives, shifting from repositories of organizational artefacts to strategic assets able to impact on organizational activities (Nissley and Casey, 2002). In parallel, corporate museums emerged as a valuable instrument to preserve collective memory of the past embedded in the industrial heritage (Amari, 2001), thus carving out a relevant role in the development of industrial tourism, especially in Italy (Garofano et al., 2017). Nevertheless, as stated above, several aspects still remain unexplored both in management and tourism fields. So far, no research efforts have been made to investigate the phenomenon of corporate museums in a way that takes more account of their strategic priorities and posture, investigating their actual willingness to contribute to the development of industrial tourism in the area, by cooperating with other local stakeholders.

The present study aimed precisely to examine corporate museums as a vehicle to extend the tourist and cultural offer of a place, by assessing their strategic orientation. The data we collected allowed us to 
propose a categorization of corporate museums based on their actual strategic orientation and therefore on the role played as platforms from which firms may directly communicate with tourists and other stakeholders. Thus, the categorization we propose allows to identify the strategic characteristics of corporate museums that may concretely shape their role in the development of tourism in a specific area.

Our findings demonstrate the high heterogeneity of corporate museums, whose strategic priorities and orientation may vary significantly. Such variety has relevant implications for their potential role in the enhancement of the tourist attractiveness of the area.

In particular, our results revealed that the majority of the investigated corporate museums (51\%) fall into the "strategist" cluster, namely they gave the highest importance to all strategic priorities considered in the analysis. These museums made significant efforts to complement their offer with that of other cultural and leisure institutions, in order to improve the appeal of the whole area and, thus, the overall experience proposed to potential visitors. In other terms, these corporate museums actively contribute to the tourism in their area.

It is worth noting that the "strategist" museums are also characterized by the highest level of firmmuseum coordination, that is they are highly dependent on the owning companies in fixing their own objectives and partnerships. And, as we noted above, from the statistical point of view, the most significant difference among the three groups is namely in terms of firm-museum coordination.

It follows that in the case of "strategist" museums the owning firms are directly and extremely involved in the local socio-cultural and economic environment, and they make use of the museums as a means for dialoguing with the local communities, based on common experience and history. These firms are perfectly aware of the potential of corporate museums, in terms of both internal and external stakeholders' engagement. And thanks to such strategic vision they manage and organize their museums in order to enhance their attractiveness and, thus, the potential interest of tourists and visitors towards their facilities. In sum, we can conclude that the strategic orientation showed by museums falling in the "strategist" cluster is a consequence of the strategic orientation of the owning firms and their direct and full control over the museums.

As noted also in previous studies (Otgaar, 2012), consumer-oriented firms have an initial advantage compared to firms without this orientation, especially for attracting industrial tourists with a leisure motivation. Thus, it is the presence of firms with a strong strategic vision that makes corporate museums a tourist destination, perfectly integrated into the overall tourist offer of the area and able to differentiate this offer for the specific target of industrial tourists.

As a confirmation of such evidence, the group that showed the minimum level of collaborative orientation is the "individualist" one, which accounts for $26 \%$ of our sample. Also the museums in this cluster are characterized by high level of firm-museum coordination, thus the owning firm is directly involved in drawing up the museum's strategy and goals.

The "individualist" museums are not open to cooperate with other cultural or leisure institutions in order to provide alternatives for visitors or to offer joint initiatives, because the owning firms do not see this as a necessity. Such firms are not actively involved in the local communities and they probably do not pursue any objectives of social value creation. They make use of the museums mainly for internal purposes, trying to engage internal stakeholders, but occasionally involving external visitors and 
tourists as well, without a clear strategic picture of the real potentialities of the museum. Of course, in so doing they do not contribute in any way to the development of the tourism in the area.

As we know from the literature, in fact, industrial tourism constitutes a complex system and its success is related to several attributes, dealing with economic, social, physical and emotional spheres, that can be fulfilled thanks to the collaboration among a number of institutions within a shared plan (Xie, 2006). In this perspective, the lack of collaborative orientation normally prevents the development of a virtuous circle based on heritage enhancement. The collaboration with other forms of leisure or tourism is essential to complement the offer of corporate museums, which is normally not sufficient to attract relevant segments of visitors towards industrial sites, especially when they are outside the consolidated tourism circuits. And this is the case of many of the museums in the "individualist" cluster.

On the other hand, the case is completely different for museums that fall into the "traditionalist" cluster, representing the $23 \%$ of our sample, that are also characterized by very high levels of collaborative orientation. These museums have a more consolidated and long-term presence in the area. Therefore, they are recognized as economic operators on their own and they autonomously manage to dialogue with other local stakeholders. The owning firms are not much involved in the strategy of the "traditionalist" museums which represent a lever of value creation for the territory but also for the company. In fact, these museums are mainly oriented to the development of the company's image and competences, more than to economic results. Thus, they are conceived mainly for the engagement of internal stakeholders, rather than for the attraction of occasional visitors.

These are museums that have been created above all for the internal needs of the companies, to preserve and pass on the history of the company to the future generations, the managers, the employees and other internal customers, and which are not seen by companies as real tourist destinations. This is the reason why the owners do not put many efforts in formulating precise strategic aims for the "traditionalist" museums and they do not invest heavily for their organization and management. However, due to the reputation, the longevity and the heritage of the brand and/or of the products, these museums attract visitors and enrich the image of the place. Thus, the attractiveness of the "traditionalist" museums is directly linked to the strength and the awareness of the brand and/or of the product, and not to a specific strategy of the firms.

The almost spontaneous arrival of visitors pushes these museums to better organize the visitor experience, looking for complementary and support elements in the area to their own offer. Thus, the "traditionalist" museums are actively oriented towards the collaboration with other forms of tourism or leisure. The weakness of these museums, in fact, is represented by the exiguous investments of the owning companies. And this is evident, for instance, from their orientation towards innovation, that in this cluster is the lowest.

Such an evidence deserves careful reflections, due to the growing importance of innovation and new technologies for the improvement of the visit experience. Indeed, many tools can be used to strengthen the narrative power of the museum, including virtual places where documentary resources are made available for visitors at any time (Camarero and Garrido, 2012). The recent experience of the lockdown caused by the spread of Covid-19 has shown how important these virtual places can be to guarantee an experience for visitors even at a distance. This is evident for museums in general and also for corporate museums. More generally, attention to innovation is necessary for the long-term sustainability of the "traditionalist" museums and for their ability to maintain their attractiveness and contribute to the tourist development of the area. 
As a final note, we tried to investigate whether belonging to one or the other cluster may be linked to specific organizational characteristics of the museums (i.e., admission method, museum timetable, number of employees, and year of foundation) and/or to environmental variables (i.e., industry, and geographical location). Significant differences emerged only in the entrance mode and in the timetable adopted by the three groups.

Therefore, the competitive characteristics of the industry in which the owning firms of the museums operate do not affect the museums' strategic orientation and their active collaboration with other local stakeholders. Similarly, the results show that there are no "spillover" effects linked to the geographical location of museums. Even if the management literature states that companies that are geographically close, and perhaps active in the same industries, tend to stimulate each other, adopting similar strategies (e.g., Porter, 1990), it seems that there is not any imitative logic confined to specific areas or industries. In fact, the museums belonging to the three clusters are distributed in the same way among the various Italian regions and the different industries.

Furthermore, our results show that not even the size or longevity of the museum helps to explain the differences between the clusters. Thus, for instance, the largest and most structured museums are not the most strategically oriented, as one might think.

Our study shows that corporate museums may take on a central role in the development of a common agenda between firms and territories, which is essential for composing the multiple interests of all stakeholders directly and indirectly involved in industrial tourism. In this direction, corporate museums and other institutions enclosing cultural heritage of a city or a region must be tied together in a mechanism of cooperation aimed at strengthening local identity while promoting synergies with tourism. In the majority of the investigated cases, such a mechanism is already working, thanks to the presence of visionary firms running and orienting "strategist" museums. For about a quarter of the investigated cases this mechanism also works, albeit in a different and less strategic way. For the "traditionalist" museums, in fact, it is the presence of historical brands to attract visitors to the area, even without too many investments of the companies. However, in a long term perspective there is also a need for these museums of a more coherent and strategic approach, including a major orientation to innovation. What deserves a great attention is that for about a quarter of the investigated cases this mechanism of cooperation between the multiple stakeholders of the area does not work. "Individualist" museums are managed by firms without a clear and complete picture of their real potentialities, with the consequence that the development of industrial tourism is really compromised in these areas.

\section{Conclusions, limitations and directions for future research}

In conclusion, our results enrich the current literature on industrial tourism, by offering an innovative categorization of corporate museums. Furthermore, our findings suggest how tourism and corporate heritage can engage in a virtuous circuit to improve the competitiveness of both firms and territories. The great cultural heritage enclosed in industrial sites represents an opportunity to develop sustainable forms of tourism. Indeed, the integration of industrial sites in tourism does not only affect economic and environmental sustainability of regions and cities, but also diversifies their tourism offer, potentially enhancing their profile as leading tourism destinations.

Of course, this study is not without limitations. First, it is acknowledged in literature that strategic orientation is contextual, that is it needs to be aligned with context for best results. Environmental and organizational variables have to be considered to reduce the potential for misleading inferences about the contribution of strategic orientation (e.g., Lumpkin and Dess, 1996). In the present study, we did 
not consider neither external variables (e.g., the effective level of development of tourism in the area, the presence of other forms of tourism attractions, and so on) nor internal variables (e.g., the effective level of investments to promote the attractiveness of the museum, the number of joint projects with other local stakeholders, and so on). It is, therefore, recommended that further studies will be undertaken to examine the role of contextual variables in determining industrial tourism destinations. Second, we used a structured questionnaire to collect perceived data from key informants (i.e., museum director/curator). Even if this method is largely used and has been proved to be effective, it could lead to biased reporting. In the future, we recommend the use of factual and secondary data on corporate museums' strategic priorities.

Third, this study has explored the managerial views and opinions toward the strategic orientation of corporate museums. We did not consider the perspective of visitors and the way they experience every aspect of the site. Understanding their expectations and levels of satisfaction would give important clues in developing and marketing corporate museums as key attractions within industrial tourism circuits. Future research should take into consideration the visitors' point of view also to further validate the categorization of corporate museums we proposed.

Finally, we focused our study just on one country (i.e., Italy). In order to overcome the possible constraint of country-specific destination attributes, future studies could be carried out in different countries with a view to uncovering new attributes that are also relevant to industrial tourism attractiveness. A suggestion for future research would consist in analysing corporate museums along with other tools for the development of industrial tourism, in order to verify how the different outcomes of these tools cohere and what managerial tools should be used to integrate them properly.

We believe that the above-mentioned points may represent interesting directions for future research to expand the present study.

\section{References}

Amari, M. (2001). I musei delle aziende: la cultura della tecnica tra arte e storia, Milano: Franco Angeli.

Boros, L., Martyin, Z., Pàl, V. (2013). Industrial tourism: trends and opportunities, Forum geographic, 12(1), 108-114.

Bulegato, F. (2008). I musei di impresa in Italia: Dalle arti industriali al design, Roma: Carocci.

Camarero, C., Garrido, M.J. (2008). The influence of market and product orientation on museum performance, International Journal of Arts Management, 10(2), 14-26.

Camarero, C., Garrido, M. J. (2012). Fostering innovation in cultural contexts: Market orientation, service orientation, and innovations in museums, Journal of service research, 15(1), 39-58.

Chen Y., Morrison M., (2004). Manufacturing a new source of visitors: a pilot study of industrial tourism in the U.S. Paper presented at the Annual conference proceedings of research and academic papers, Vol. XVI, $26^{\text {th }}-28^{\text {th }}$ September, 113-128.

Cole, D. (2004). Exploring the sustainability of mining heritage tourism. Journal of sustainable tourism, $12(6), 480-493$.

Coleman, L. V. (1943). Company museums. American association of museums, Washington DC: The American Association of Museums.

Danilov, V.J. (1992). A planning guide for corporate museums, galleries, and visitor centers, Westport: Greenwood Publishing Group.

Edwards, J.A., Llurdés i Coit, J.C. (1996). Mines and quarries: Industrial heritage tourism. Annals of tourism research, $23(2), 341-363$. 
Frew, E. A. (2008) Industrial tourism theory and implemented strategies. In Woodside, A. G. (ed.) Advances in Culture, Tourism and Hospitality Research. Volume 2. Bingley: Emerald Group Publishing Limited, 27-42.

Garofano A., Riviezzo A., Napolitano M. R. (2017). From industrial heritage to living industry tourism. An explorative study in Italy. In Jimenez Caballero J.L., Gonzalez Rodriguez M.R., Simonetti B., Squillante M., (ed.), Proceedings book II International Conference on Tourism Dynamics and Trends, Universidad de Sevilla, $26^{\text {th }}-29^{\text {th }}$ June $2017,210-230$.

Garofano A., Riviezzo A., Napolitano M.R. (2020), Una storia, tanti modi di raccontarla. Una nuova proposta di definizione dell'heritage marketing mix / One story, so many ways to narrate it. A new proposal for the definition of the heritage marketing mix. IL CAPITALE CULTURALE. Studies on the Value of Cultural Heritage, Supplementi 10 (2020), 125-146.

Hair, J. F., Jr., Black, W. C., Babin, B. J., Anderson, R. E. (2010). Multivariate data analysis (7th ed.). New Jersey: Pearson Prentice Hall.

Hoek, J., Gendall, P., Esslemont, D. (1996). Market Segmentation: A Search for the Holy Grail?. Journal of Marketing Practice, 2(1), 25-34.

Hospers, G. (2002). Industrial Heritage Tourism and Regional Restructuring in the European Union. European Planning Studies, 10(3), 397-404.

Lane, J. B. (1993). Oral history and industrial heritage museums. The Journal of American History, 8o(2), 607-618.

Lee, C. F. (2016). An investigation of factors determining industrial tourism attractiveness. Tourism and Hospitality Research, 16(2), 184-197.

Lumpkin, G. T., Dess, G. G. (1996). Clarifying the entrepreneurial orientation construct and linking it to performance. Academy of management Review, 21(1), 135-172.

Mitchell, M. A., Mitchell, S. J. (2001). Consumer experience tourism: A powerful tool for food and beverage producers. Journal of Food Products Marketing, 6(3), 1-16.

Mitchell, M. A., Orwig, R. A. (2002). Consumer experience tourism and brand bonding. Journal of Product $\mathcal{E}$ Brand Management, 11(1), 30-41.

Montella, M. M., Cerquetti, M. (2016). Il ruolo dei musei aziendali nel marketing del made in Italy: tipologie e posizionamento strategico. In Napolitano M. R., Marino V. (ed.), Cultural heritage e made in Italy. Casi ed esperienze di marketing internazionale, Napoli: Editoriale Scientifica, 407-437.

Montella, M. M. (2010). Musei d'impresa come strumento di comunicazione. Possibili innovazioni di prodotto, processo, organizzazione. Esperienze d'Impresa, 2, 147-163.

Montella, M. M. (2012). Marketing del cultural heritage territoriale e musei di impresa. Un caso di analisi. Mercati e Competitività, (4), 33-51.

Montemaggi, M., Severino, F. (2007). Heritage marketing: la storia dell'impresa italiana come vantaggio competitivo, Milano: Franco Angeli.

Napolitano, M.R., Riviezzo, A. Garofano, A. (2018). Heritage Marketing. Come aprire lo scrigno e trovare un tesoro, Napoli: Editoriale Scientifica.

Napolitano, M.R., Riviezzo, A. Garofano, A. (2020). Musei d'impresa: luoghi della memoria, dell'identità e dell'innovazione organizzativa. In: D’Alessandro L., Collina S., Affinito M., (a cura di). I beni culturali nell'era digitale: tra tradizione e innovazione, p. 95-109, Soveria Mannelli: Rubbettino Editore.

Negri, M. (2003). Manuale di museologia per i musei aziendali, Soveria Mannelli: Rubbettino Editore.

Nissley, N., Casey, A. (2002). The Politics of the Exhibition: Viewing Corporate Museums through the Paradigmatic Lens of Organizational Memory. British Journal of Management, ${ }_{13}\left(\mathrm{~S}_{2}\right), \mathrm{S}_{35}-\mathrm{S}_{45}$.

Otgaar, A.H.J. (2012). Towards a common agenda for the development of industrial tourism. Tourism management perspectives, 4, 86-91. 
Otgaar, A.H.J., Van Den Berg, L., Berger C., Xiang Feng R. (2010). Industrial Tourism. Opportunities for City and Enterprise, Farnham: Ashgate.

Piątkowska, K. (2014). The Corporate Museum: A New Type of Museum Created as a Component of Marketing Company. International Journal of the Inclusive Museum, 6(2), 29-37.

Porter, M.E. (1990). The competitive advantage of nations, New York: Free Press.

Ravasi, D., Rindova, V. P., Stigliani, I. (2018). History, material memory and the temporality of identity construction, Academy of Management Journal, Published Online:15 Oct 2018, https://doi.org/10.5465/amj.2016.0505.

Riviezzo, A., Garofano, A., Napolitano, M. R. (2016). "Il tempo è lo specchio dell'eternità". Strategie e strumenti di heritage marketing nelle imprese longeve italiane. IL CAPITALE CULTURALE. Studies on the Value of Cultural Heritage, 13, 497-523.

Stigliani I., Ravasi D. (2007), Organizational artefacts and the expression of identity in corporate museums at Alfa-Romeo, Kartell, and Piaggio. In L. Lerpold, D. Ravasi, J. van Rekom, G. Soene (Eds.) Organizational Identity in Practice, London and New York: Routledge, 197-214.

Xie, P. F. (2006). Developing industrial heritage tourism: A case study of the proposed jeep museum in Toledo, Ohio. Tourism Management, 27(6), 1321-1330.

Yang, X. (2017). Industrial heritage tourism development and city image reconstruction in Chinese traditional industrial cities: a web content analysis. Journal of Heritage Tourism, 12(3), 267-280.

Voss, G.B., Voss, Z.G. (2000). Strategic orientation and firm performance in an artistic environment, Journal of marketing, 64(1), 67-83.

Received: 31/03/2020

Accepted: 20/10/2020

Coordinating editors: Giacomo Del Chiappa and Anestis K. Fotiadis 